Winter 2003

\title{
Democracy in Global Environmental Governance: Issues, Interests, and Actors in the Mekong and the Rhine
}

Tun Myint

Darmouth College

Follow this and additional works at: https://www.repository.law.indiana.edu/ijgls

Part of the Environmental Law Commons, and the International Law Commons

\section{Recommended Citation}

Myint, Tun (2003) "Democracy in Global Environmental Governance: Issues, Interests, and Actors in the Mekong and the Rhine," Indiana Journal of Global Legal Studies: Vol. 10 : Iss. 1 , Article 11.

Available at: https://www.repository.law.indiana.edu/ijgls/vol10/iss1/11

This Symposium is brought to you for free and open access by the Law School Journals at Digital Repository @ Maurer Law. It has been accepted for inclusion in Indiana Journal of Global Legal Studies by an authorized editor of Digital Repository @ Maurer Law. For more information, please contact rvaughan@indiana.edu.

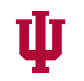

JEROME HALL LAW LIBRARY

INDIANA UNIVERSITY

Maurer School of Law
Blooming ton 


\title{
Democracy in Global Environmental Governance: Issues, Interests, and Actors in the Mekong and the Rhine
}

\author{
TUN MYINT** \\ INTRODUCTION
}

This paper presents a study of the Mekong River Commission (MRC) and the International Commission for Protection of the Rhine (ICPR). The primary focus of this study is to analyze and explain how the issues, interests, and participation of local communities and non-state actors, such as industries and non-governmental organizations, are incorporated or not incorporated into transnational environmental governance in the MRC and ICPR regimes. Analyzing issues, interests and actors across three layers-local, national, and transnational-of the MRC and ICPR, this paper argues that the spirit of democracy can be enhanced in global environmental governance. Although states remain central players in the governance of global environmental resources, non-state actors have made striking advances both in the creation of environmental regimes and in efforts to make these regimes function effectively

* The first version of this paper was presented at the 2001 Berlin Conference on Human Dimensions of Global Change: Global Environmental Change and Nation States, Berlin, December 6-9, 2001.

** IDGEC Research Fellow, Institutional Dimensions of Global Environmental Change project (Dartmouth College); Research Assistant, Center for the Study of Institutions, Population, and Environmental Change at Indiana University-Bloomington; Ph.D. Candidate, School of Public and Environmental Affairs and Indiana University School of Law. The author benefited from the comments of various individuals in the process of writing this paper and wishes to thank Professors Elinor Ostrom, Michael McGinnis, and participants at the CIPEC Colloquium on November 1,2001 at the Workshop in Political Theory and Policy Analysis. He also thanks Professor Ronald Mitchell of University of Oregon for taking time to comment, as well as Mr. Simon Mason of Swiss Federal Institute of Technology (ETH), Zurich for his insightful comments. During research in Rhineland, the author received kind assistance from various individuals. He wants to acknowledge Professor Thomas Bemauer, Mr. Raphaël Tschanz, and Mr. Simon Mason for their continued support during his stay at CIS at ETH. For their time and assistance, thanks also go to Secretary Mr. J. Harm Oterdoom and Deputy Secretary Dr. Ann Schulte-Wülwer-Leidig of ICPR (IKSR) in Koblenz, Germany, Mr. Edwin Müller of the Swiss Delegation, Mr. Bob Dekker of the Dutch Delegation, Professors Erik Mostert and Pieter Huisman of the Center for Research on River Basin Administration at the University of Delft in the Netherlands, and Dr. Peter Stoks of WRK Water Works in Nieuwegein, the Netherlands. The author also thanks Dr. Edith Wenger of WWF and Flood Plain Institute, Rastatt, Germany, and Dr. Reina Kuiper of Stichting Reinwater of Amsterdam, the Netherlands for their help with his research. Without the help from all of these individuals, the research in Rhineland would not have been possible. Finally, all errors and incompleteness are the author's alone. 
once they are in place. ${ }^{1}$ This phenomenon of increased participation of nonstate actors and local communities is evident in the governance of the Mekong and Rhine River Basin.

The international system, in which nation-states are the key players, is going through a period of transformation. The phenomena of democratization, economic globalization, environmental degradation, and regional integration ${ }^{2}$ are creating a global transformation that is shaping the future of the nationstate, as well as the future of the international system. Describing the challenges of global transformation, Robert $\mathrm{O}$. Keohane argues that the "key problem of world order now is to seek to devise institutional arrangements that are consistent both with key features of international relations and the new shape of domestic politics." ${ }^{\prime 3}$ In his presidential address to the 2000 American Political Science Association Meeting, Keohane further asserted that "the effective governance of global issues will be dependent upon interstate cooperation and transnational networks." ${ }^{\text {"4 }}$ Global transformation means that the traditional international regimes that were built by the power of states and interstate relations have become ineffective institutions, especially in regard to global environmental issues. ${ }^{5}$ In dealing with global environmental issues, global solutions "require local approaches when global environmental crisis results from both the aggregation of local resource decisions and from the impact of the global political economy on local communities." This raises the question of whether transnational environmental regimes that are designed to foster interstate cooperation and transnational networks, such as the MRC and ICPR, are desirable or effective forms of governance for global environmental issues that are simultaneously linked to the local context.

1. See generally THOMAS PRINCEN \& MATTHIAS FINGER, ENVIRONMENTAL NGOS IN WORLD POLITICS: LINKING THE LOCAL AND THE GLOBAL (1994); PAUL WAPNER, ENVIRONMENTAL ACTIVISM IN WORLD POLITICS (1996); RONNIE D. LIPSCHUTZ \& JUdITH MAYER, Global CIVIL SOCIETY AND Global ENVIRONMENTAL GOVERNANCE: THE POLITICS OF NATURE FROM PlaCE to PlaNet (1996).

2. See generally THE GLOBAL TRANSFORMATIONS READER: AN INIRODUCTION TO THE GLOBALIZATION DEBATE (David Held \& Andrew McGrew eds., 2000) [hereinafter THE Global TRANSFORMATIONS READER]; LOCAL COMMONS AND GLOBAL INTERDEPENDENCE: HETEROGENEITY AND COOPERATION IN TWO DOMAINS (Robert O. Keohane \& Elinor Ostrom eds., 1995); Stephen D. Krasner, Compromising Westphalia, 20 INT'L SeCurity 115 (1995); Global TRansformation: Challenges to the State System (Yoshikazu Sakamoto ed., 1994) [hereinafter CHALLENGES TO THE STATE SYSTEM].

3. Robert O. Keohane, Sovereignty in International Society, in THE Global TRANSFORMations READER, supra note 2, at 119.

4. Robert O. Keohane, Governance in a Partially Globalized World, 95 AM. POL. SCI. REV. 1, 1 (2001).

5. See THE Global TRANSFORMATIONS READER, supra note 2, at 105-90. See generally CHALLENGES TO THE STATE SYSTEM, supra note 2.

6. PRINCEN \& FINGER, supra note 1 , at 221. 
Within these transnational regimes, there are three layers of governing institutions: local institutions composed of individuals and industries, national institutions in each member state composed of ministerial and municipal governments, and transnational institutions made up of national delegations at the transnational level and other non-state actors such as donors and nongovernmental environmental organizations. These layers are institutionally interconnected in the governance process. Within each layer, issues, interests, and actors shape political processes. The presence of these issues, interests, and actors in each layer, as well as the strength of networks among them, creates a dynamic political process. I will define this whole process as the "governance process." Though governance by governments of states has traditionally been the study of international affairs, governance nowadays is a phenomenon of managing and networking issues, interests, and actors to produce transparent actions in process and to achieve the stated goals of regimes. This paper, in an attempt to develop a model that explains how democracy can function in transnational environmental governance, examines issues, interests, and actors in MRC and ICPR regimes.

Part I lays out the theoretical puzzles that form the essence of this paper. Part II discusses the Issues, Interests, and Actors Network (IAN), employing insights from the Institutional Analysis and Development (IAD) framework developed at the Workshop in Political Theory and Policy Analysis at Indiana University-Bloomington. Part III discusses the current states of the Mekong and the Rhine in brief. Part IV applies the IAN framework tool to break down and analyze governance processes mainly of the Rhine regimes. Finally, I conclude with remarks on democracy and transnational environmental governance in three layers of transnational regimes in the Rhine and in the Mekong River Basins.

\section{THEORETICAL PUZZLE}

The subject of global environmental governance has been dominated chiefly by the study of environmental regimes. Political scientists' work advances the study of international regimes. Their emphasis has been on understanding how international affairs may effectively be governed by regimes that are designed to achieve stated goals and objectives. Political scientists' interest is in how cooperation among sovereign states can be augmented in 
order to solve problems that are transnational in nature. ${ }^{7}$ In 1989 , Peter Haas posed the question: "do regimes matter?"8 Haas's fundamental question prompted the study of whether regimes make any difference to the international environmental affairs which they address. Oran R. Young answered Haas's question: "We can state without hesitation that regimes do matter in international society, so that there is nothing to be gained from perpetuating the debate between neo-institutionalists and neo-realists about the 'false promise of international institutions."

If regimes matter, how do we measure their effectiveness? The emphasis on the effectiveness of international regimes is heightened by the emergence of global issues such as environmental degradation, trade disputes, disease control, and conflict resolution. These global crises not only require international cooperation, but also demand actions beyond traditional diplomacy. The study of international affairs has traditionally been confined to the study of power and diplomatic relations among sovereign states. However, regime analysts look beyond a realist approach to the study of international affairs and further advance a transnational perspective to global governance by drawing insights from the experiences of international environmental regimes. ${ }^{10}$ As Michael Zürn asserted in a major review of the progress of research on international environmental politics, study of regime effectiveness has become the "driving force" in the analysis of global environmental governance. ${ }^{11}$

The study of regime effectiveness that Zürn refers to as a "driving force" in environmental governance focused significantly on the attainment of the stated goals of regimes. ${ }^{12}$ However, the definition of regime effectiveness will not be complete without the study of the process of governance involved in

7. See Matthijs Hisschemöller \& Joyeeta Gupta, Problem-Solving Through International Environmental Agreements: The Issue of Regime Effectiveness, 20 INT'L POL. SCI. REV. 151 (1999); see also Detlef F. Sprintz \& Carsten Helm, The Effect of Global Environmental Regimes: A Measurement Concept, 20 INT'L POL. SCl. Rev. 359, 361 (1999); Lisa L. Martin \& Beth Simmons, Theories and Empirical Studies of International Institutions, 52 INT'L ORG. 729, 742 (1998).

8. See generally Peter M. Haas, Do Regimes Matter? Epistemic Communities and Mediterranean Pollution Control, 43 INT'L ORG. 377 (1989).

9. THE EFFECTIVENESS OF INTERNATIONAL ENVIRONMENTAL REgIME: CAUSAL CONNECTIONS AND BEHAVIORAL MECHANISMS 249 (Oran Young ed., 1999); see also John J. Mearsheimer, The False Promise of International Institutions, 19 INT'L SECURITY 5-49 (1995).

10. See generally GLOBAL GOVERNANCE: DRAWING INSIGHTS FROM THE ENVIRONMENTAL EXPERIENCE (Oran R. Young ed., 1997).

11. See Michael Zürn, The Rise of International Environmental Politics: A Review of Current Research, 50 WORLD POL. 617, 649 (1998).

12. See Thomas Bernauer, The Effect of International Environmental Institutions: How We Might Learn More, 49 INT'L ORG. 351, 369 (1995). 
transnational environmental regimes. Stated goals can be achieved by an authoritarian regime or by a supranational authority, but environmental governance in the global context must address equity issues (or the issue of democratic deficit) among regime actors in multiple layers. The successes or failures of regimes are determined predominantly by how resources are used and managed at the local layer. In search of better or more democratic processes for transnational issues governance, Robert A. Dahl asked whether international organizations can be democratic. ${ }^{13}$ While Peter Haas is concerned mainly with analyzing the outcomes of regimes (such as international organizations) against an alternative situation in which no regimes were present to address the relevant problem, ${ }^{14}$ Dahl questions the processes of these regimes in producing outcomes. ${ }^{15}$ In other words, while Haas is concerned with the outcomes of regime presence, Dahl addresses the democraticness of the processes that produce outcomes. Both Haas's and Dahl's research complement the question of how we can best shape governance processes within layers of institutions in solving global environmental problems that are simultaneously linked to local layers, a question that is at the heart of this paper. In other words, this paper will address how we might enhance democracy in the context of transnational environmental governance.

If regimes matter, we must also ask what types of regimes work best for transnational environmental governance. Regime design has become the current focus of debate on environmental governance across the field. Variations among different scales and different types of regimes produce different outcomes. At the local level, some resource appropriators (or users) find ways to use resources in a manner that is sustainable over time and some do not. ${ }^{16}$ In similar fashion, it is still unresolved why some international regimes are successful while others are not. ${ }^{17}$ In essence, regime design matters for global environmental governance. ${ }^{18}$ It matters not only for effectiveness in

13. Robert A. Dahl, Can International Organization Be Democratic? A Skeptic's View, in DEMOCRACY'S EDGES 19 (lan Shapiro \& Casiano Hacker-Cordon eds., 1999).

14. Haas, supra note 8 , at $401-03$.

15. Dahl, supra note 13 , at 32-34.

16. See Elinor Ostrom et. al, Revisiting the Commons: Local Lessons, Global Challenges, 248 SCIENCE 278,278 (1999).

17. See The EFfectiveness of INTERNATIONAL ENVIRONMENTAL REgIMES: Causal ConNections AND BEHAVIORAL MECHANISMS (Oran R. Young ed., 1999) [hereinafter THE EFFECTIVENESS OF INTERNATIONAL ENVIRONMENTAL REGIMES].

18. See generally Ronald B. Mitchell, Regime Design Matters: International Oil Pollution and Treaty Compliance, 48 INT'L ORG. 425 (1994). 
producing outcomes, but also for equity and faimess in the governance process. That is, appropriation of resources among stakeholders must be managed in a fair process and efficient manner. It has been further argued that "effective and humane global governance arrangements are not inevitable;", rather, regimes must be designed. However, regime design will make sense "only to the extent that it involves understanding of the ways institutions are likely to work in practice." ${ }^{20}$ Therefore, the design of regimes governing transnational environmental resources must be sensitive to and reflective of the economic, political, and social contexts within which the regimes operate.

Environmental governance is an inherently political process. Furthermore, it is a unique political process because the natural environment, or set of biogeophysical systems, is essentially a non-human actor. Young articulates the uniqueness of environmental governance by labeling it as a "Problem of Fit," that is, of whether the institutional arrangements designed to solve environmental problems are congruent or compatible with the bio-geophysical systems they address. However, I would expand on this by stating that there are two parts to the "problem of fit." The first part is whether the environmental regimes that are designed to serve human needs (not desires) fit the economic, social, and political contexts within which they operate. The second part is whether the environmental regimes fit the bio-geophysical systems they address. Therefore, the "problem of fit" as a whole, must simultaneously address both human systems and bio-geophysical systems. This "fit" puzzle is another reason to investigate whether the MRC and ICPR fit human systems and the bio-geophysical systems they address.

Which part of the "problem of fit" is more important than the other is a rather interesting question. In this paper, I would argue that the first part of the problem of fit as a whole is more important, especially from the dimension of governance processes, and that the second part of the problem of fit is dependent upon the first part. If environmental regimes fit the human systems, they are more likely to fit bio-geophysical systems. Therefore, in this paper, I will strive for a deeper understanding of the role that issues, interests, and actors play in the dynamic process of environmental governance in the MRC and ICPR regimes. In so doing, I will break down and analyze governance

19. See Keohane, supra note 4 , at 12.

20. See Oran R. Young, The Institutional Dimensions of ENVIRonmental Change: Fit, INTERPLAY, AND SCALE 5 (2002).

21. Id. at 55 . 
processes across and between local, national, and transnational layers of the MRC and ICPR. The focal question to answer is whether local ${ }^{22}$ and nonstate $^{23}$ actors are crucial to the success ${ }^{24}$ of environmental governance in the MRC and ICPR.

Methodologically, to explain the environmental governance of transnational environmental resources, it is important to understand the institutional linkages among various layers of transnational environmental regimes. Within the lens of institutionalist theory, transnational regimes can be conceptually separated into three layers-local, national, and transnational layers. In order to analyze and explain how issues, interests, and actors interplay and what linkages between these layers are in the governance process, I will apply the framework of "scaling down" and "scaling up," i.e. a combination of both top-down and bottom-up approaches. ${ }^{25}$ There are both formal and informal institutional linkages between the three layers of the MRC and ICPR. Through these linkages, the issues, interests, and actors in each layer are interconnected and emerge as institutional drivers to operate the regimes' governance processes.

\section{AN ANALYTICAL FRAMEWORK FOR ISSUES, INTERESTS, AND ACTORS}

\section{A. Interplay of Issues, Interests, and Actors}

Two sources of literature serve as a starting point to theorizing about the interplay of issues, interests, and actors in the environmental governance processes of the MRC and ICPR regimes. The first source is the works of Arthur F. Bentley, who pioneered the study of "group interest" to explain the political influence of pressure groups on the three branches of the U.S. government. In his work The Process of Government, published in 1908, Bentley asserts, " $[\mathrm{t}]$ here is no group without its interest $[\mathrm{s}]$.... The group and the interest are not separate ... . If we try to take the group [for analysis]

22. I define the term "local actor" as a local stakeholder whose decision-making capacity is directly affected by policy and laws of national government and transnational institutions.

23. I define a "non-state actor" as a stakeholder whose interests cross multiple legal jurisdictions and political boundaries, and whose decision-making capacity is directly affected by the policy and laws of MRC and ICPR.

24. I define "success" or "effectiveness" of a regime to mean both fair process of governance and achievement of the regime's stated goals. Fair process requires all actors to play their respective important roles in the governance process.

25. See generally Oran R. Young, The Effectiveness of International Environmental Regimes, in GOVERNANCE IN WORLD AFFAIRS 108 (1999). 
without the interest, we have simply nothing at all."26 In studying the governance processes of the MRC and ICPR, the fundamental elements of analysis are institutions and formally and informally established groups. The interests of MRC and ICPR institutions cannot be ignored by scholars, for analytical purposes, or by practitioners, for practical purposes. Bentley argues that special interests are the "raw materials of politics." ${ }^{27}$ I further assert that they are the raw materials of effective and fair governance processes. Bentley believes that political campaigns of local activists and lobbyists, their acts of pressure, persuasion, conflict, and collusion, are not to be denounced or deplored, but rather described and understood. ${ }^{28}$ Furthermore, interests are the driving force not only for lobbyist groups, but also for governments. In a democratic governance system, the interests of politicians and electoral representatives collectively become the engine of governance. Therefore, the study of governance processes must analyze the dynamic interplay of interests in relation to issues and actors.

The second source of literature is the works of Harold D. Lasswell and Myres McDougal on "law, science, and policy." 29 In a series of unpublished lecture notes that were compiled and documented at Indiana University School of Law in 1954, Lasswell explains what he calls "social process" as a mechanism by which "persons influence one another to pursue values." $\mathrm{He}$ writes:

When two persons influence one another, we speak of the process as social .... In a world shrinking at an ever accelerating rate because of relentlessly expanding, uniformlyimposing technology, the people of the globe as a whole constitute a world community, which in turn is composed of a myriad of smaller communities .... Acting as individuals and in concert, the participants in all social processes, large and small, pursue values through institutions using resources. ${ }^{30}$

26. ARthur F. Bentley, The Process of Government: A Study of SoClal Pressures 211,213 (1908).

27. Id. at 176 .

28. See id. at $175-99$.

29. HAROLD DWIGHT LASSWELL \& MYRES MCDOUGAL, LAW, SCIENCE AND POLICY (1954) (unpublished lecture notes on file with the Indiana University School of Law Library).

30. Id., pt. II, ch. I, para. 1. 
Social process, Lasswell explains, is the mechanism by which individual actors pursue values in society. In essence, Lasswell's assertion conveys that actors are guided mainly by the values they uphold in society. However, actors' choices are always constrained by either issues or interests. Issues are socially and politically crafted. For instance, as will be discussed later in this paper, the issue of Rhine pollution was not on the political agenda of riparian countries until the Dutch government initiated establishment of the transnational regime in $1950 .^{31}$ Investigative journalism and specific issue-oriented nongovernmental environmental organizations such as the World Wildlife Fund (WWF) or Greenpeace often raise environmental issues to the policy agenda across institutional layers.

\section{B. Issues, Interests, and Actors Network (IAN)}

Interests are mainly economically driven, issues are socially and politically crafted, and actors are value-oriented in the interplay of Issues, Interests, and Actors Network model (IAN). When there is a strong presence of these issues, interests, and actors with respect to a particular environmental problem in each layer of a transnational regime, effective cooperation among actors for environmental governance will more likely be achieved. In a world of highly interdependent heterogeneous forces that shape the process of governance, the governance process must be fair. The fairness of the governance process is a crucial parameter for the fitness of regimes to the social, political, and economic contexts within which the regimes operate.

"Network," in IAN, refers to a complicated intermingling of lines, linkages, passages, roads, individuals, and layers of institutions that makes it possible for regimes to achieve certain objectives that require various independent elements (issues, interests, and actors) to work together. If various issues, interests, and actors are to function effectively, there must be institutional arrangements that enable them to work in unison. This union can be established when actors are willing and able to work with interests and issues transparently. Constructive cooperation of various actors is possible only with a free flow of information, allowing linkages between IANs to develop and design a transnational governance mechanism.

Based on preliminary findings from my research on the MRC and ICPR, environmental governance processes can be explained by analyzing Issues,

31. See infra note 54 and accompanying text. 
Interests, and Actors Networks within each layer of transnational environmental regimes. In the form of a network, issues, interests, and actors interdependently shape one another to become the engine of a governance process, as shown in Figure I below.

By analyzing regime governance with the IAN model, we find that issues finally become agenda, interests become essentially organized interests, and actors become stakeholders (Figure I). The important assumption in the process is that although issues, interests, and actors are interdependent, they do not have absolute control over one another.

Figure I: Process of Issues, Interests, and Actors Network

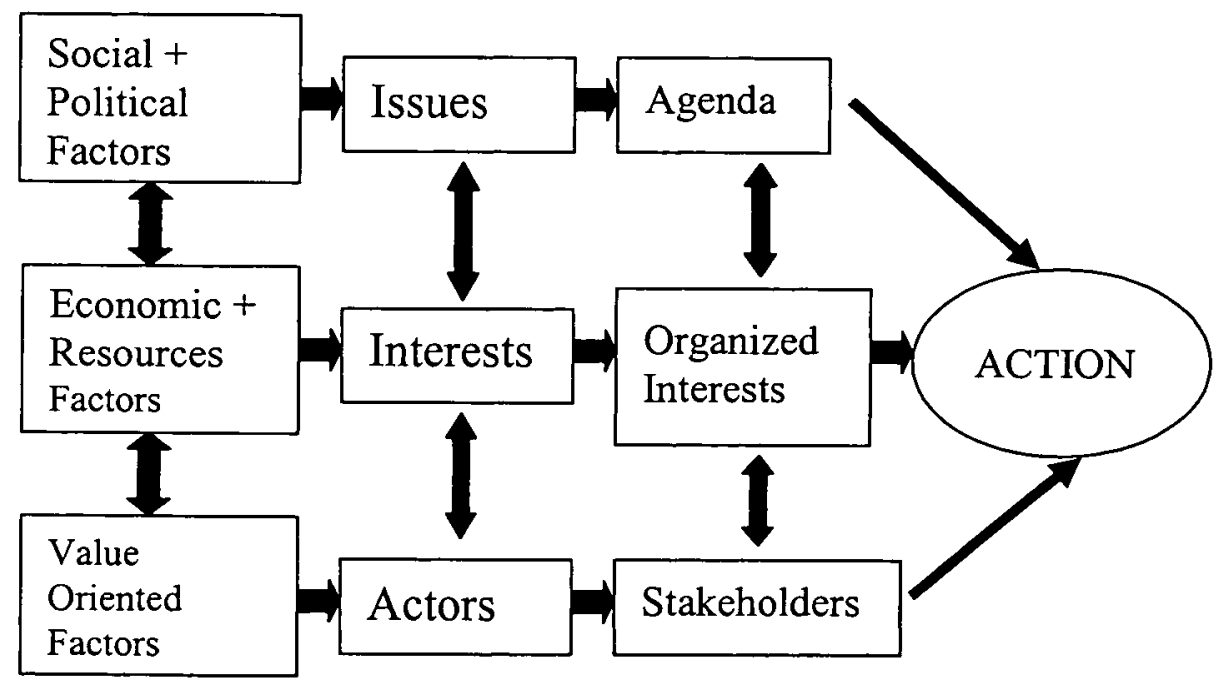

For instance, the issue of water quality of the Rhine was not a primary political and social concern in the context of pre-1950 Rhine regimes. Rather, the issues of navigation and fishing quotas were perceived as problems for many countries at that time. The dominant existence of the international Rhine treaty on Navigation, signed in $1868,{ }^{32}$ and the 1885 Salmon Treaty ${ }^{33}$ illustrate

32. Convention Revisee Pour la Navigation du Rhin [Mannheim Convention], Oct. 17, 1868, in 1 U.N. FOOD AND AGRICULTURE ORGANIZATION, SYSTEMATIC INDEX OF INTERNATIONAL WATER RESOURCES TREATIES, DeClarations, ACTS AND CASES By BASIN, Legislative STUDY No. 15, at 89 (1978).

33. Staatsvertrag über die Lachsfischerei im Rhein [International Treaty on Salmon Fishing in the Rhine], June 7, 1886; see Alexandre Charles Kiss, La Pollution du Rhin et le Droit International Public, in LA 
that the water quality of the Rhine was not a significant issue for the Rhine Regime. Finally, in the 1950s, the government of the Netherlands put the water quality issue on the agenda for international affairs and initiated the establishment of the ICPR in 1950. Even though the issue of water quality of the Rhine, a priori, had existed since industrialization began along the bank of the river, no political institutions raised this issue as one to be solved by means of international cooperation until the Dutch government politicized it. Due to increasing costs in the purification process for water supplies companies in the Netherlands, the Dutch government was positioned to include water pollution issues on the international political agenda among the Rhine riparian countries. As the lowest country downstream, the Netherlands had a legitimate interest to raise at the international level.

In the Mekong river basin area, environmental issues such as water pollution and ecosystem destruction are still in the stage of infancy. That is, these issues have yet to become policy agenda in local and national layers. Poverty reduction and trust-building among the riparian countries are at the active stage of interplay at the local layer. Compared to the Rhine regime, the Mekong regime is at the preventive stage with the issue of water pollution. The Rhine regime, on the other hand, is at the rehabilitation stage. As we shall see in the following sections, governance processes of the MRC and ICPR essentially are shaped by the presence and interplay of IANs in each layer of a regime.

\section{THE MEKONG RIVER COMMISSION AND THE INTERNATIONAL COMMISSION FOR THE PROTECTION OF THE RHINE}

\section{A. The Mekong River Commission}

The Mekong is the world's twelfth longest river. Originating from its headwaters on the Tibetan Plateau, it runs 4,193 kilometers south through the Yunnan Province of China, Myanmar (Burma), Laos P.D.R., Thailand, Cambodia, and Vietnam. More than fifty million people depend upon the Mekong River and its tributaries for food, water, transportation, and many other aspects of their daily lives. The river's annual flood-drought cycles are

POLLUTION DU RHIN: ASPECTS JURIDIQUES, ÉCONOMIQUES ET TECHNIQUES [RHINE POLLUTION: LEGAL, ECONOMIC, AND TECHNICAL ASPECTS] 59-80 (R. Hueting ed., 1978). 
essential for the sustainable production of food crops on the floodplains and along the banks of the rivers during the dry season. ${ }^{34}$

The Mekong river basin is the second richest in biodiversity among the world's river basin areas. It has been a life support system for human survival in the region. The $1999 \mathrm{MRC}$ annual report states that "some 45-50 million people are employed in the agriculture sector. Rice is the most important crop, but fisheries follow rice cultivation almost invariably. [T] ogether with rice, fish forms the basis of the food security for the people in the Lower Mekong Basin." 35 Therefore, the sustainable utilization of water and natural resources in the Mekong region is the main concern for riparian countries.

\section{B. Institutional Evolution of the $M R C$}

The MRC has evolved through three stages of institution building. The first stage began with the establishment of a transnational governing body known as the Mekong Committee in 1957, initiated by the United Nations. The original Committee members were Cambodia, Laos P.D.R., South Vietnam, and Thailand. The Mekong Committee originated within the Bureau of Flood Control of the United Nations Economic Commission for Asia and Far East (ECAFE), now known as the United Nations Economic and Social Commission for Asia and Pacific (ESCAP). The Mekong Committee was the first transnational governing body in the region, and thus it is a pioneer in regional cooperation in Southeast Asia.

The second stage of evolution came at the end of the second Indo-China war, with the triumph of North Vietnam over South Vietnam. Communist victories in Cambodia, Laos, and Vietnam in 1975 almost ended the Mekong Committee, as the three Communist states refused to participate in the functions of the Committee. Meanwhile, Vietnam invaded Cambodia and ousted the Khmer Rouge by installing a pro-Vietnamese government in Cambodia. However, with the diplomatic negotiations initiated by the United Nations, the Mekong Committee was transformed into the Interim Mekong Committee (IMC), composed of Laos, Vietnam, and Thailand, in 1978. The 1978 IMC Statute called for the reactivation of the Mekong Committee when Cambodia

34. Nmns Bandara Nawarathna et al., Influence of Human Activities on the BTOPMC Model Runoff Simulations in Large-Scale Watersheds, in XXIX LAHR Congress Proceedings, Theme A (Sept. 16-21, 2001), available at http://www.iahr.org/e-library/beijing_proceedings/HTML/homepage.html.

35. Mekong River Commission, Annual Report 1999, at 21, at http://www.mrcmekong.org/pdf/annrep.pdf [hereinafter MRC Annual Report]. 
rejoined. ${ }^{36}$ Cambodia rejoined and a reactivated Mekong Committee replaced the IMC with the signing of the Declaration of November 4, 1991 in Bangkok.

The third stage of institutional evolution emerged when the Cold War was winding down in Southeast Asia. This geopolitical transformation opened up new prospects for cooperation in the Mekong region. As the rivals in the Cambodian civil war signed a peace agreement in Paris in 1991, Cambodia prepared to reenter the Mekong regime. Once again, negotiations initiated by the United Nations took place in various stages to reconstruct the Mekong regime. This series of negotiations led to a political agreement in which the lower Mekong riparian countries - Cambodia, Laos P.D.R., Thailand, and Vietnam-agreed to establish the MRC on April 5, 1995 in Thailand. With this final stage of institutional establishment, the MRC replaced the Mekong Committee established in 1957 and the IMC established in 1978. China and Myanmar did not seek to join the MRC, as these two countries did not see the benefits of joining the regime.

\section{MRC Institutional Design}

The MRC is structured with three permanent bodies-the Council, the Joint Committee, and the Secretariat. ${ }^{37}$ The Council is composed of one member from each MRC member country at the Ministerial and the Cabinet levels. ${ }^{38}$ The Council convenes annually and produces policy guidelines, represents national initiatives, resolves conflicts, and makes policy decisions. ${ }^{39}$ The Council's decisions are made by unanimous consensus. The Secretariat's office provides necessary technical assistance in this process. The Secretariat also facilitates the participation of non-governmental organizations, donors, and those with local concerns in the policy process of the Council and in the implementation process at the national level. In each member state, there is a National Mekong Committee (NMC) responsible for carrying out functions of

36. See generally Communique Concerning the Mekong Committee, in Declaration Concerning the Interim Mekong Committee for Coordination of Investigations of the Lower Mekong Basin, Jan. 5, 1978, LaosThailand-Vietnam (available in Greg Browder, Negotiating an International Regime for Water Allocation in the Mekong River Basin (1998) (Ph.D. dissertation, Stanford University)).

37. Agreement on Cooperation for the Sustainable Development of the Mekong River Basin, Apr. 5, 1995, art. 12, at http://www.mrcmekong.org/pdf/agree95.pdf [hereinafter Agreement on Cooperation]

38. Id., art. 15. See also MRC Annual Report, supra note 35, at 2, 4-6.

39. Agreement on Cooperation, supra note 37, at art. 18. See also MRC Annual Report, supra note 35, at $2,4-6$. 
national policy and programs agreed to at the MRC transnational level. NMCs thus oversee implementation of programs at the local level.

\section{MRC Programs}

The MRC's objective is "to co-operate in all fields of sustainable development, utilisation, management and conservation of the water and related resources of the Mekong River Basin. ${ }^{, 40}$ In order to achieve this objective and to implement the Mekong Agreement, the MRC has launched three core programs that call for the active participation of national and local communities. First, in accordance with Articles 5 and 6 of the Mekong Agreement, which mandate water utilization and ecological protection, the MRC inaugurated the Water Utilisation Programme (WUP) in $1999 .{ }^{41}$ The 1999 MRC Annual Report alleges that the WUP will be "a major test-case for the potential for regional co-operation on the development and use of the Mekong river basin resources. Its implementation will also be a major test-case on the effectiveness and relevance of the Mekong River Commission itself.,"42

Second, along with the WUP, the MRC began to launch Basin Development Planning (BDP) in 2000 with the target of completion in $2003 .^{43}$ $\mathrm{BDP}$ is "envisaged as both a general planning tool and a process which will be used by the joint Committee as a blue-print for identifying and prioritizing programs and projects at basin-wide level" in order to realize sustainable development of the Mekong region. ${ }^{44}$ The MRC's Secretariat is responsible for assisting the Joint Committee with technical and administrative works to accomplish BDP.

The third major program that is being implemented is the MRC Environment Training Programme (MRC-EP) ${ }^{45}$ The MRC-EP will provide scientific data and technical advice to the MRC for carrying out programs and projects in sustainable ways. The MRC-EP therefore is the key program in addressing the environmental impacts of other MRC programs such as dam projects, irrigation, and water utilization programs. In addition to the three core programs, there are five area programs. These are the Fisheries Program, the

40. Mekong River Commission, About MRC, at http://www.mrcmekong.org/about_mrc/about001.htm (last visited Nov. 13, 2002).

41. MRC Annual Report, supra note 35, at 19.

42. Id.

43. Id. at $19-20$.

44. Id. at 19.

45. See id. at 23-25. 
Agriculture, Irrigation, and Forestry Program, the Water Resources and Hydrology Program, the Navigation Program, and the Tourism Program. ${ }^{46}$

\section{E. The International Commission for the Protection of the Rhine}

The Rhine River originates in the Swiss Alps, where two tributaries (the Hinterrhine and the Vorderrhine) flow down and collide at the village of Reichenau-Tamin. From that point on, the Rhine weaves through valleys to reach Lake Constance. This part of the Rhine is called the Alpine Rhine. After leaving Lake Constance, the river flows down to the chemical industrial city called Basel (or Basle in French). This part of the Rhine is known as the High Rhine. Along the Alpine and High Rhine, until it forms Europe's largest falls, called the Rhinefalls, at the village of Neuhausen, the river is wild, active, and dynamic in its course of flow.

The Rhine is Western Europe's largest river, at 1,326 kilometers in length. ${ }^{47}$ At its origin in the glaciers of the Swiss Alps, it constitutes the border between Switzerland, Liechtenstein, and Austria until it reaches Lake Constance (Bodensee). It then continues to form the border between Germany and France, after leaving Basel to flow through a large part of western Germany, and finally crosses into the Netherlands and pours into the North $\mathrm{Sea}^{48}$ The Rhine's catchment area covers 22,400 square-kilometers and encompasses parts of Italy, Luxembourg, and Belgium. The catchment area provides a habitat for about sixty million people in addition to other living organisms. ${ }^{49}$

Humans and other inhabitants use the Rhine in a variety of ways. The Rhine was historically important for water transportation, and is still widely used as a shipping route, with the world's largest seaport, located in Rotterdam, at its mouth. ${ }^{50}$ The problem of water quality was one of the first issues that prompted the riparian countries to consider cooperation, due to industrial buildup on the bank of the river. Although the problems with the quality of water in the Rhine were already recognized in the fifteenth century, "it was not until the 20th Century that the advanced stage of water pollution in the river

46. See generally id.

47. Carel H.V. de Villeneueve, Western Europe's Artery: The Rhine, 36 NAT. RESOURCES J. 441 (1996).

48. Id.

49. Id.

50. $I d$. 
became clearly apparent." ${ }^{\text {51 }}$ Europe's industrialization process had a great impact on the Rhine ecosystem. By the early 1960s, the pollution of the Rhine by organic substances had lowered the level of dissolved oxygen well below normal levels, and as a consequence, almost all aquatic life had disappeared from the river. "Large amounts of heavy metal compounds, pesticides, hydrocarbons, and organic chlorine compounds were being discharged into the river." ${ }^{.52}$ This obviously caused further ecological problems, notably the disappearance of native fish species and the continued deterioration of the water quality. "By the end of the 1960s, the Rhine had the unflattering reputation of being the sewer of Europe." $"$ s3

\section{F. Emergence of International Cooperation}

The deterioration of the Rhine's water quality and degradation of natural resources were the obvious reasons that the Rhine's future required effective international cooperation. From the perspective of the historical evolution of the relationship between the ecosystems of the Rhine and its human inhabitants, the end of World War II marked the beginning of a new chapter in the Rhine's history. In 1950, with an initiative from the Netherlands, the riparian countries of the Rhine located downstream from Lake Constance-Switzerland, France, Germany, Luxembourg (through the tributary river Moselle), and the Netherlands-joined forces by establishing, on a rather informal basis, the $\mathrm{ICPR}^{54}$

During the ICPR's first decade, it served as a common forum for discussion of pollution in the Rhine. In 1963, however, the ICPR parties concluded that the existing tools for cooperation among governments should be strengthened, and formalized the Commission's existence through an agreement at Berne, adding a permanent joint secretariat at Koblenz, Germany. In the ICPR agreement signed at Berne, "the ICPR was entrusted with the following tasks:

- studying the nature, volume, and origins of the Rhine pollution;

- proposing appropriate measures to control pollution to the governments of contracting parties;

51. See Koos Wieriks \& Anne Schulte-Wülwer-Leidig, Integrated Water Management for the Rhine River Basin: From Pollution Prevention to Ecosystem Improvement, 21 NAT. RESOURCES F. 147, 148 (1997).

52. Id. at 149.

53. Id.

54. de Villeneueve, supra note 47 , at 443. 
- preparing further agreements between the governments of contracting parties;

- undertaking any other task jointly entrusted to it by the governments of contracting parties; and

- drawing up a yearly report on its activities."

In 1976, the ICPR agreement was amended to enable the European Economic Community (EC, the predecessor of the EU) to join. The EC's accession to ICPR had become inevitable in view of its newly developing environmental regulations, particularly in the field of water pollution within EC jurisdiction. ${ }^{56}$ As a consequence of the EC's environmental regulation regime, its member states could no longer conclude agreements with non-EC states such as Switzerland. Therefore, the EC's participation in the ICPR was important for the ICPR's future as well as for the uniformity of EC environmental regulation. The EC commission, since then, has fully participated in the ICPR and has shared its costs. In matters falling under EC competence, it exerts its voting right on behalf of EC member states in the ICPR (which includes all ICPR states except Switzerland). However, it is interesting to note that the EC does not function as a member state within the ICPR in matters of implementation and administration of ICPR agreements, since these functions are left to the member states.

\section{G. ICPR Regime Outlook}

With the five member countries plus the European Union, the ICPR regime has transformed from a treaty-type regime to an action-oriented regime. There are three major mechanisms of ICPR environmental governance. The first two are legally binding treaties - the 1976 Convention for the Protection of the Rhine Against Chemical Pollution (Chemical Convention) ${ }^{57}$ and the 1976 Convention for the Protection of the Rhine Against Pollution by Chloride (Chloride Convention). ${ }^{58}$ The third and most famous mechanism is the Rhine Action Programme inaugurated in 1987 and concluded in $2000,{ }^{59}$ which was a

55. Id. at 444; see also Agreement on the Int'l Comm'n for the Protection of the Rhine Against Pollution, Apr. 29, 1963, 993 U.N.T.S. 18, at art. 2.

56. de Villeneueve, supra note 47 , at 445 .

57. Convention on the Protection of the Rhine against Chemical Pollution, Dec. 3 1976, 16 I.L.M. 242 (1977), available at http://www.fletcher.tufts.edu/multi/texts/BH697.txt [hereinafter Chemical Convention].

58. Convention for the Protection of the Rhine River Against Pollution by Chlorides, Dec. 3, 1976, 16 I.L.M. 265 (1977) [hereinafter Chloride Convention]

59. See de Villeneuve, supra note 47 , at 452 . 
non-binding action oriented program. These three regime designs for ICPR environmental governance are the central focus of my analysis using the IAN model.

\section{LAN ANALYSIS OF THE ICPR}

\section{A. Issues, Interests, and Actors in the 1976 Chemical Convention}

The aim of the Chemical Convention was to reduce pollution of the Rhine by gradually eliminating discharges of hazardous chemical elements including heavy metals from chemical industries, community sewage systems, and agricultural land.$^{60}$ The first step in achieving these goals was the formation of black and gray lists for regulation. The black list was to include most toxic chemical substances, and the reduction of discharges of these substances was to become a priority. ${ }^{61}$ The gray list was to include chemical substances that were less toxic but that still needed regulation. ${ }^{62}$ However, the implementation has met with difficulties.

At the transnational level, during the first three decades of the ICPR regime, the key issue has been building trust among national delegations. According to Peter Huisman, a former Secretary actively involved in the ICPR from 1971 to 1985 , trust building among the member states took an enormous amount of time and effort. ${ }^{63}$ Another important reason why the Chemical Convention was not as successful as hoped was because of the lack of political will at the national level. Environmental issues at the time were not so important to national economies, while industrialization was at its peak for building stronger economies in member countries. According to Huisman, getting all of the countries to come together at the meeting to discuss Rhine pollution was itself a significant step at the beginning. ${ }^{64}$ However, it was accomplished not entirely due to national political will, but also because local "pressure groups" raised issues of Rhine pollution publicly.

Another issue at the negotiation meetings was whether the industries were capable, in terms of resources and technology, of implementing pollution

60. See id. at 449.

61. See id. (outlining measures related to "list I").

62. See id. (outlining measures related to "list II").

63. Interview with Pieter Huisman, River Basin Administration, University of Delft, Netherlands (July 5, 2001) [hereinafter Huisman Interview].

64. Id. 
reduction standards-especially effluent limits—set by the Chemical Convention. The effluent limits set the maximum allowable limit on pollutant chemicals in discharged wastewater from industries. This is different from the general water quality standard. If industries discharged wastewater into the Rhine containing pollutant chemicals that exceeded the effluent limit, the effluent fee was assessed. For many industries, paying the effluent fee was not a major issue; ${ }^{65}$ the major issue was rather the capacity to reduce the content of pollutant chemicals entirely. For the ICPR, under pressure from the Netherlands, the solution is not about assessing effluent fees, but about cleaning the Rhine River by reducing the discharge of eighty-three blacklisted chemicals. ${ }^{66}$

Meanwhile, the German delegation suggested implementation of the EUwide effluent limit. ${ }^{67}$ German industries supported this suggestion, because if the effluent limit applied to only the Rhine basin industries, they would be at a disadvantage compared with other EU chemical industries, such as British chemical industries, in the common market outside of Rhine basin areas. ${ }^{68}$ Therefore, the EU regional approach was discussed. This analysis also helps to explain why the European Community joined ICPR as a full-fledged member in 1976. Because the EU became a member of the ICPR, it was feasible for it to discuss a regional approach to effluent limits as suggested by the German delegation.

65. See Marco VerweiJ, Transboundary ENVIRonmental Problems and Cultural Theory: The PROTECTION OF THE RHINE AND THE GREAT LAKES 116 (2000).

66. Id. at 116-18.

67. Huisman, supra note 63.

68. See Carel Dieperink, Between Salt and Salmon: Network Management in the Rhine Catchment Area, in MaNaging EnVIRonmental Disputes: Network MaNagement aS aN Alternative 119, 128-29 (Peter Glasbergen ed., 1995); VERWEIJ, supra note 65, at 83. 
Table I: Issues, Interests, and Actors Network in the Chemical Convention

\begin{tabular}{|c|c|c|c|}
\hline $\begin{array}{c}\text { Institutional } \\
\text { Layers }\end{array}$ & Issues & Interests & Actors \\
\hline Transnational & $\begin{array}{l}\text { - Chemical } \\
\text { pollution of the } \\
\text { Rhine ( } 83 \text { in } \\
\text { black list) } \\
\text { - Building } \\
\text { international } \\
\text { cooperation } \\
\text { - Industrial } \\
\text { compliance }\end{array}$ & $\begin{array}{l}\text { - Downstream } \\
\text { pressure } \\
\text { - Cost of effluent } \\
\text { limit } \\
\text { - Regional } \\
\text { approach for cost } \\
\text { sharing }\end{array}$ & $\begin{array}{l}\text {-ICPR } \\
\text { - Germany and } \\
\text { Switzerland } \\
\text { - The Netherlands } \\
\text { - National } \\
\text { Delegations }\end{array}$ \\
\hline National & $\begin{array}{l}\text { - Lack of political } \\
\text { will } \\
\text {-Lack of trust in } \\
\text { other member } \\
\text { states } \\
\text {-Perceived as } \\
\text { international } \\
\text { problem }\end{array}$ & $\begin{array}{l}\text { - Cost of regulation } \\
\text {-Pressure from } \\
\text { chemical } \\
\text { industries } \\
\text { - Pressure from } \\
\text { water supply } \\
\text { companies (the } \\
\text { Netherlands) }\end{array}$ & $\begin{array}{l}\text {-Ministerial } \\
\text {-Municipal } \\
\text {-Industries }\end{array}$ \\
\hline Local & $\begin{array}{l}\text {-Drinking water } \\
\text { supply } \\
\text {-Public health } \\
\text {-Sewer image }\end{array}$ & $\begin{array}{l}\text { - Cost of } \\
\text { compliance } \\
\text { - Cost of drinking } \\
\text { water } \\
\text { - Health risk } \\
\text { - Recreation }\end{array}$ & $\begin{array}{l}\text {-Chemical } \\
\text { industries } \\
\text {-Water supply } \\
\text { industries } \\
\text {-Communities of } \\
\text { interests } \\
\text { - Local NGOs }\end{array}$ \\
\hline
\end{tabular}

The Chemical Convention, however, was finally stalled, due to the conflict that arose in 1979 between the Netherlands and France regarding chloride pollution when the Netherlands called back its ambassador from Paris for consultation. However, the major reason for the failure of the Chemical Convention is that all the relevant issues and actors were not involved in the entire process of negotiation and implementation. Neither NGOs nor the industries were invited, nor were they regarded as important actors in the process at the national and transnational layers. The ICPR regime was 
functioning based on a state-centered approach, as if states were the most important players in transnational environmental governance. Additionally, the binding nature of the regime design was an indicator that member countries did not trust each other, fearing a serious free-rider problem. A lesson from the Chemical Convention is that environmental governance cannot be successful without taking into account all relevant issues, interests, and actors across the three layers of the regime.

\section{B. Issues, Interests, and Actors in the 1976 Chloride Convention}

The main agenda of the Chloride Convention focused on the Alsatian mine company, Potasse de'Alsace, in France, which was responsible for thirty-five to forty percent of the total discharge of 400 kilograms of chloride (salt) per second $(\mathrm{kg} / \mathrm{s})$ into the Rhine. ${ }^{69}$ The chloride discharges were especially harmful to the interests of several Dutch water companies, flower growers, and the port of Rotterdam. According to the negotiated treaty, the discharges of the mine company were to be cut by $60 \mathrm{~kg} / \mathrm{s}$ in three phases. ${ }^{70}$ In this process, the salts that were not discharged into the Rhine were to be injected into the Alsatian earth. The estimated cost was 132 million French francs. ${ }^{71}$ The agreement provided that the Netherlands would finance thirty-four percent of the project, Germany and France would each pay thirty percent of the costs, and Switzerland would pay the remaining six percent. ${ }^{72}$ For a number of years, the French government was reluctant to consider Alsatian salt and the Rhine issue on its agenda of parliament ratification, as it was occupied with two other issues. The first was rising unemployment in France, and the second was the labor strike in the Alsatian mines. ${ }^{73}$ Additionally, some in France worried that the proposed solution would cause groundwater pollution. ${ }^{74}$ As a result, France delayed its compliance with the agreement. This caused direct conflict with the Netherlands, which was facing heavy pressure from local water supply industries and the port of Rotterdam. The Dutch government recalled its ambassador from Paris for consultation, and the relationship between France

69. de Villeneuve, supra note 47 , at 446.

70. Id.

71. See VERWEIJ, supra note 65 , at 84 .

72. Id.

73. Huisman Interview, supra note 63.

74. de Villeneuve, supra note 47 , at 447. 
and the Netherlands deteriorated as a result of the fallout over the Chloride Convention. $^{75}$

The Chloride Convention is the least favorite topic of discussion for ICPR leaders. When asked about the Chloride Convention, the current deputy Secretariat of the ICPR described it as "the worst experience" of the ICPR regime, because it caused many other obstacles not closely related to the chloride case. ${ }^{76}$ As a result of the chloride controversy, the whole ICPR regime was stalled; no other issues were discussed due to the intense conflict on the issue. The key problem, once again, was the lack of political will within member states, especially in France. In addition, low levels of trust and cooperation among the member states also caused difficulties.

Table II: Issues, Interests, and Actors in the Chloride Convention

\begin{tabular}{|c|c|c|c|}
\hline $\begin{array}{c}\text { Institutional } \\
\text { Layers }\end{array}$ & Issues & Interests & Actors \\
\hline Transnational & $\begin{array}{l}\text { - Conflict between } \\
\text { the Netherlands } \\
\text { and France } \\
\text {-International } \\
\text { cooperation } \\
\text {-ICPR's role } \\
\text { challenged }\end{array}$ & $\begin{array}{l}\text { - Cost of } \\
\text { operation } \\
\text { - Downstream } \\
\text { pressure } \\
\text { - Defining } \\
\text { responsible party } \\
\text { to pay for cleanup }\end{array}$ & $\begin{array}{l}\text {-ICPR } \\
\text { - France } \\
\text { - The Netherlands } \\
\text { - National } \\
\text { Delegations }\end{array}$ \\
\hline National & $\begin{array}{l}\text { - Lack of political } \\
\text { will } \\
\text {-Unemployment } \\
\text { and labor strike in } \\
\text { France } \\
\text {-International } \\
\text { problem }\end{array}$ & $\begin{array}{l}\text {-Damage to farm } \\
\text { land } \\
\text {-Pressure from } \\
\text { water industries } \\
\text { - Pressure from } \\
\text { Alsatian mine } \\
\text { workers } \\
\text { - Faith of ICPR } \\
\text { regime }\end{array}$ & $\begin{array}{l}\text {-Diplomats } \\
\text { - Ministries } \\
\text {-Municipals } \\
\text {-Water supply } \\
\text { and mining } \\
\text { industries }\end{array}$ \\
\hline
\end{tabular}

75. Id.

76. Interview with Anne Schulte-Wülwer-Leidig, Koblenz, Germany (July 25, 2001) [hereinafter SchulteWulwer-Leidig Interview]. 


\begin{tabular}{|l|l|l|l|}
\hline Local & $\begin{array}{l}\bullet \text { Drinking water } \\
\text { supply } \\
\bullet \text { Public health }\end{array}$ & $\begin{array}{l}\bullet \text { Cost of water } \\
\text { purification } \\
\bullet \text { Loss of }\end{array}$ & $\begin{array}{l}\bullet \text { Local farmers } \\
\bullet \text { Alsatian mining } \\
\text { industry in }\end{array}$ \\
& $\bullet$ Agriculture & $\begin{array}{l}\text { agricultural land } \\
\text { from salinization } \\
\text { in the } \\
\text { Netherlands }\end{array}$ & $\begin{array}{l}\text { France } \\
\bullet \text { Water supply } \\
\text { industries in the } \\
\end{array}$ \\
& & $\begin{array}{l}\text { Netherlands } \\
\bullet \text { NGOs }\end{array}$ \\
\hline
\end{tabular}

\section{Issues, Interests, and Actors in the Rhine Action Program}

The ICPR's further development as an effective transnational regime was perhaps sparked by the Sandoz chemical accident. ${ }^{77}$ Pieter Huisman called the Sandoz spill a "gift from heaven" in that it raised awareness of the seriousness of the need for rehabilitation of the Rhine. ${ }^{78}$ On November 1, 1986, a fire broke out at a storage building for dangerous chemicals at a Swiss pharmaceutical company near Basel, Switzerland. ${ }^{79}$ The firefighters arrived in time to extinguish the fire. However, the water used to extinguish the fire mixed with the dangerous chemicals, and eventually reached the adjacent stretch of the Rhine. As a consequence, a several hundred-mile stretch of the Rhine became ecologically dead. ${ }^{80}$ This disaster received large press coverage, and the ICPR parties reacted swiftly. On November 12, 1986, the ministers held joint meetings and assessed the remedial process. At the same time, Sandoz's chief executives joined the ministerial meeting and explained what went wrong. As the incident triggered a wave of publicity in all the countries bordering the Rhine, political attention was alerted, and within a very short time several ministerial conferences were addressing the issue of Rhine pollution. With environmental issues already high on the political agenda in many countries in the mid-1980s, the 1986 Sandoz accident spurred the ICPR to implement the Rhine Action Programme for Ecological Rehabilitation (RAP) in $1987^{81}$

77. See Alyssa Glass \& Carrie Snyder, Shocked into Action: Combating Pollution in the Rhine, 18 HARV. INT'L REV. 48 (1996); de Villeneuve, supra note 47, at 451.

78. Huisman Interview, supra note 63.

79. Glass \& Snyder, supra note 77, at 48.

80. Id.

81. de Villeneuve, supra note 47 , at 451 . 
The combination of political opportunity, the Sandoz accident, the existence of an institutional framework, and the extensive and responsive preparatory work carried out by the ICPR laid the foundation for the emergence of the RAP. The RAP had the following four goals, to be attained by the year 2000: the Rhine ecosystem should be improved to such an extent that higher species, such as salmon and sea trout, return to the Rhine; the production of drinking water from the Rhine must be guaranteed for the future; the pollution of river sediments must be reduced to such an extent that at any time sludge may be used for land fill or may be dumped at sea; and the improvement of the ecology of the North Sea must be a requirement of the North Sea Program. ${ }^{82}$

The RAP's first goal, enabling the return of species such as salmon, is perhaps the most ambitious of its four goals, since salmon are migratory fish and require different river habitats for spawning, nursery, and migration. The return of salmon is further complicated by the fact that they require unobstructed passage in the river for upstream migration, a condition that has been eliminated due to the weirs, locks, and dams regulating the river. Salmon are also dependent on other river species that require varied habitats and are sensitive to pollution for food. Therefore, reintroduction of the salmon requires high water quality and restored hydrological and morphological conditions. ${ }^{83}$ Since the return of salmon requires the restoration of a complex set of conditions, the ICPR has elaborated on its first goal in the Ecological Master Plan for the Rhine. ${ }^{84}$

By 2000 , the success of both the RAP and pollution control programs were reported. The UNESCO Courier report in June, 2000 called it the "Miracle of the Rhine," reporting the findings of scientists that salmon and other species of fish had returned to the Rhine's waters. ${ }^{85}$ The environmental media watching the ICPR's programs described the RAP as a "model for future. ${ }^{186}$ The

82. Id. at 451-52. The North Sea Program aims to reduce pollution and nutrient loading in the North Sea. See generally G.M. Van Dijk et al., Ecological Rehabilitation of the River Rhine: Plans, Progress and Perspectives, 11 REGULATED RIVERS: RES. \& MGMT. 377-88 (1995).

83. Salmon are particularly sensitive to the quality of water in their habitat. Therefore, the RAP's goal of enabling the return of salmon means improving water quality to levels in which other species can also survive. Van Dijk, supra note 82, at 377; Schulte-Wulwer-Leidig Interview, supra note 76; Huisman Interview, supra note 63; see also International Commission for the Protection of the Rhine, Salmon 2000, at http:// www.iksr.org/icpr/louk.htm.

84. de Villeneuve, supra note 47 , at 453.

85. See Urs Weber, The "Miracle" of the Rhine, THE UNESCO COURIER, June 2000, at 9.

86. See Glass and Snyder, supra note 77 , at 75 . 
European Union issued a water directive in July 2000 that was modeled after the success of the transnational cooperation among the Rhine countries.

Table III: Issues, Interests, and Actors Network in the Rhine Action Program

\begin{tabular}{|c|c|c|c|}
\hline $\begin{array}{c}\text { Institutional } \\
\text { Layers }\end{array}$ & Issues & Interests & Actors \\
\hline Transnational & $\begin{array}{l}\text { - Transparency of } \\
\text { all Rhine issues } \\
\text {-NGOs } \\
\text { participation and } \\
\text { public education } \\
\text {-Monitor member } \\
\text { states' } \\
\text { implementation } \\
\text {-Maintain mutual } \\
\text { trust } \\
\end{array}$ & $\begin{array}{l}\text {-Ecological loss } \\
\text { - Revitalization of } \\
\text { the Rhine } \\
\text { ecosystems } \\
\text { - Maintaining and } \\
\text { increasing } \\
\text { coordination } \\
\text { among actors }\end{array}$ & $\begin{array}{l}\text {-ICPR } \\
\cdot \text { EU } \\
\cdot \text { National } \\
\text { Delegations } \\
\cdot \text { NGOs } \\
\text {-Industries }\end{array}$ \\
\hline National & $\begin{array}{l}\text {-Building fish } \\
\text { passages by } \\
\text { removing weirs } \\
\text { and locks } \\
\text {-Enforcing } \\
\text { domestic } \\
\text { regulations }\end{array}$ & $\begin{array}{l}\text { - Reduce long-term } \\
\text { cost } \\
\text { - Maintaining } \\
\text { national integrity } \\
\text { and value }\end{array}$ & $\begin{array}{l}\text {-Ministerial } \\
\text { level } \\
\text {-Municipal } \\
\text { governments } \\
\text {-Industries } \\
\text { - National NGOs }\end{array}$ \\
\hline Local & $\begin{array}{l}\text { - Demand for } \\
\text { recreational } \\
\text { activities } \\
\text {-Demand for } \\
\text { drinking water }\end{array}$ & $\begin{array}{l}\text { - Ecological health } \\
\text { of the Rhine } \\
\text {-Environmental } \\
\text { awareness and } \\
\text { value of the Rhine }\end{array}$ & $\begin{array}{l}\text {-Organized } \\
\text { water supply } \\
\text { industries } \\
\text { (IAWR }{ }^{87} \text { ) } \\
\text {-Organized } \\
\text { chemical } \\
\text { industries } \\
\end{array}$ \\
\hline
\end{tabular}

87. Internationale Arbeitsgemeinschaft der Wasserwerke im Rheineinzugsgebier [Intemational Association of Waterworks in the Rhine]. 
D. Issues, Interests, and Actors in Rhine Governance

The illustrated experiences of transnational environmental governance in the Rhine support the conclusion that a partial answer, if not the entire answer, to the question of why two previous legally binding regimes-the 1976 Chemical and Chloride Conventions-failed in achieving their stated goals was the lack of interconnectedness and institutional linkages among issues, interests, and actors across three layers. The RAP, although there is still room for improvement, transformed the Rhine regime into a mechanism of governance that opened the door to participation by various relevant actors (Table IV). In so doing, the RAP enhanced the spirit of democracy, which was crucial to the success of the Rhine rehabilitation regime. The RAP fits better into the political, social, and economic contexts within which it operated than did the Chemical and Chloride Conventions. The previous two regimes did not fit the structure of the problems of the Rhine regime because they ignored important issues, interests, and actors, especially from local layers, as we have observed in IAN analysis. As a result, the previous two regimes failed to achieve their stated goals of cleaning up the Rhine.

Table IV: Comparison of Actors in Two Types of Rhine Regime

\begin{tabular}{|c|c|c|c|}
\hline $\begin{array}{l}\text { Institutional } \\
\text { Layers }\end{array}$ & $\begin{array}{c}\text { Actors in } 1976 \\
\text { Chemical } \\
\text { Convention }\end{array}$ & $\begin{array}{l}\text { Actors in } 1976 \\
\text { Chloride } \\
\text { Convention }\end{array}$ & $\begin{array}{l}\text { Actors in Rhine } \\
\text { Action Program }\end{array}$ \\
\hline Transnational & $\begin{array}{l}\text {-ICPR } \\
\text { - Germany and } \\
\text { Switzerland } \\
\text { - The Netherlands } \\
\text { - National } \\
\text { Delegations } \\
\end{array}$ & $\begin{array}{l}\text {-ICPR } \\
\text { - France } \\
\text { - The Netherlands } \\
\text { - National } \\
\text { Delegations }\end{array}$ & $\begin{array}{l}\cdot \text { ICPR } \\
\cdot \text { EU } \\
\cdot \text {-National } \\
\text { Delegations } \\
\cdot \text { NGOs } \\
\text {-Industries } \\
\end{array}$ \\
\hline National & $\begin{array}{l}\text {-Ministries } \\
\text {-Municipal } \\
\text {-Industries }\end{array}$ & $\begin{array}{l}\text {-Diplomats } \\
\text { - Ministries } \\
\text {-Municipals } \\
\text { - Water supply and } \\
\text { mining industries }\end{array}$ & $\begin{array}{l}\text {-Ministries } \\
\text {-Municipal } \\
\text { governments } \\
\text {-Industries } \\
\text { - National NGOs }\end{array}$ \\
\hline
\end{tabular}




\begin{tabular}{|l|l|l|l|}
\hline Local & $\bullet$ Chemical & $\bullet$ Local farmers & $\bullet$ Organized \\
& industries & $\bullet$ Alsatian mining & water supply \\
& $\bullet$ Water supply & industry in France & industries \\
& industries & $\bullet$ Water supply & (IAWR) \\
& $\bullet$ Communities of & industries in the & $\bullet$ Organized \\
& interests & Netherlands & chemical \\
& $\bullet$ Local NGOs & $\bullet$ NGOs & industries \\
\hline
\end{tabular}

The empirical evidence that emerged from the experience of the Rhine not only demonstrates the importance of enhancing the spirit of democracy; it also offers some insights about the crucial relationship between democracy across multiple layers of transnational environmental regimes and the sustainability that such regimes address. The institutional arrangements that are designed to address environmental problems need to fit human systems; that is, they have to enhance democracy among actors. At the same time, they must achieve their goals in ways that fit the bio-geophysical system. According to the empirical evidence discussed above, in the context of governance of the Rhine, the institutional arrangement that fits the human system, the RAP, tends also to fit the bio-geophysical system. On the other hand, the institutional arrangements that do not fit the human system, the Chemical and Chloride Convention regimes, failed to fit the bio-geophysical system. These results suggest that transnational environmental governance must address democracy and sustainability simultaneously.

\section{CONCLUSION}

The experience of the ICPR in governing transnational environmental resources provides rich lessons for how we might enhance the democracy of transnational environmental governance while achieving sustainability. The spirit of democracy can be enhanced by promoting and providing political and legal contexts in which all relevant issues, interests, and actors in all layers can participate in decisionmaking and implementation processes. I would argue that the dynamic presence of IANs in each layer of transnational environmental governance is crucial to the success of a regime in carrying out its goals and achieving sustainability. At the same time, the spirit of democracy could be enhanced further by thinning the borders that exist between layers. As practitioners, managing the linkages among IANs across all layers will be an important task in achieving the goals of transnational environmental 
governance. Researchers, by ignoring the IANs in analysis of transnational environmental governance regimes such as the MRC and ICPR, will lack empirical evidence that is crucial to the theoretical understanding of democracy in the context of transnational environmental governance. 